\title{
A violência alteritária: a negação do outro no Brasil contemporâneo
}

\author{
The alteritarian violence: the negation of \\ the other in contemporary Brazil
}

\author{
Paulo Henrique Fonseca \\ Leonardo Lani Abreu
}

\section{Resumo}

Nunca foi tão necessário falar sobre violência quanto nos dias de hoje, nos quais as situaçōes de violação à integridade dos seres humanos atingiram um nível tão alarmante que quaisquer esperanças de um futuro mais harmônico parecem infundadas. No mundo, em geral, e no Brasil, em particular, acumulam-se os exemplos de banalização da violência, tais como os episódios recentes de ódio a imigrantes, registrados na Europa e nos Estados Unidos, e, no caso brasileiro, as decapitaçōes ocorridas durante rebeliōes em presídios, o assassinato de indígenas e trabalhadores rurais e o assalto à democracia e aos direitos sociais. Se é verdade que a humanidade sempre foi violenta, também é verdadeiro que os novos meios de comunicação, ao transformarem o mundo numa aldeia, aumentaram a percepção a respeito da violência de um modo jamais visto antes. A própria internet tem se transformado cada vez mais em uma arena em que se embatem opiniōes muitas vezes irreconciliáveis. Porém, considerando-se que o simples lamento quanto aos efeitos nocivos da violência é contraproducente, é necessário perquirir acerca das causas desse fenômeno, a fim de mitigar o sofrimento por ele causado, e uma primeira constatação é desde logo evidente: a de que a violência, ao permear, em variados graus de intensidade, todas as relaçōes humanas, desponta como um elemento estrutural da sociedade. Com isso, não se pretende dizer que essa violência alteritária, que recai sobre o "alter", o outro, e se manifesta em três níveis - intergrupal, intragrupal e individual -, seja inevitável, mas sim lançar as bases para perscrutar suas raízes, por meio da adoção de um viés interdisciplinar e do método histórico-dialético, no intuito de promover a tomada de consciência em torno da natureza da violência, tanto por parte de suas vítimas quanto de seus agentes.

Palavras-chave: Democracia; violência; poder; alteridade.

\footnotetext{
Abstract

It has never been more necessary to talk about violence than it is today, where situations of violation of human integrity have reached such an alarming level that any hopes for a more harmonious future seem unfounded. In the world in general, and in Brazil in particular, there are accumulating examples
} 


\begin{abstract}
of banalization of violence, such as recent episodes of hatred of immigrants, registered in Europe and the United States, and in the Brazilian case, the beheadings that occurred during riots in prisons, the murder of indigenous and rural workers and the assault on democracy and social rights. If it is true that humanity has always been violent, it is also true that the new media, by transforming the world into a village, increased the perception of violence in a way never seen before. The internet itself has increasingly become an arena in which many opinions are often irreconcilable. However, considering that the simple regret about the harmful effects of violence is counterproductive, it is necessary to investigate the causes of this phenomenon in order to mitigate the suffering caused by it, and a first observation is immediately evident: that violence, permeating all human relations in varying degrees of intensity, emerges as a structural element of society. This is not to say that this alteritarian violence, which falls on the "alter", the other, and is manifested on three levels - intergroup, intragroup and individual - is inevitable, but to lay the foundations for peering its roots, Through the adoption of an interdisciplinary bias and the historical-dialectical method, in order to promote awareness of the nature of violence, both by its victims and by its agents.
\end{abstract}

Keywords: Democracy; violence; power; alterity.

\section{Introdução}

Se crise é, de fato, sinônimo de oportunidade, é conveniente aproveitar o impasse com o qual o Brasil se depara para investigar as raízes do imobilismo experimentado pela maioria da população nos dias correntes. O que mais salta aos olhos, no cenário vigente, é o clima de decepção que paira no ar, evidenciado em frases como "O Brasil não tem jeito" e outras do mesmo gênero, cada vez mais proferidas, pessimismo que caminha pari passu com o crescimento da animosidade entre os integrantes das variadas camadas sociais, em razão, principalmente, de motivos políticos e religiosos. É preciso destacar, antes de mais nada, que a conturbação no ambiente político brasileiro não é um problema exclusivo do país, por estar inscrita numa problemática mais ampla, resultante, entre outros fatores, das disfunçōes da modernidade e da crise de fundamentação filosófica característica da atualidade, em que "[...] o velho morre e o novo não pode nascer" (Gramsci, 2007, p. 184).

Essa advertência se faz necessária para evitar que se incorra na atitude autodepreciativa tão disseminada entre os brasileiros, o famoso "complexo de vira-latas", "[...] inferioridade em que o brasileiro se coloca, voluntariamente, em face do resto do mundo" (Rodrigues, 2013, p. 80). A definição de Nélson Rodrigues, embora reflita, de maneira cristalina, a descrença generalizada dos brasileiros quanto às suas próprias qualidades, merece algum reparo. Afinal, baixos níveis de autoconfiança e de aspiração, responsáveis, em grande parte, pela estagnação e pobreza, não decorrem exclusivamente da vontade individual. $\mathrm{Na}$ maioria das vezes, afiguram-se como resquícios do colonialismo, processo que visa inculcar, no colonizado, o sentimento de baixa auto-estima, sem o qual a dominação não é possível, descreve Dussel: 'Todo o 'mundo' imaginário do indígena era 'demoníaco' e como tal devia ser destruído. Esse mundo do Outro era interpretado como o negativo, pagão, satânico e intrinsecamente perverso." (Dussel, 1993, p. 60).

Teorias jurídico políticas hegemônicas na modernidade, como a da ocupação e conquista como fundamento da soberania e da propriedade marcam geneticamente a formação colonial de muitos países. Maria Paula Meneses identifica no processo de imposição da racionalidade moderna europeia e seu paradigma de apropriação violenta (Meneses, 2013, p. 86). Cecília Abdo Feres no mesmo sentido registra a violência permitida no espaço colonial à margem do aparente controle estatal (Ferez, 2014, p. 12). A mentalidade violenta 
que cerca de proteção à propriedade na América Latina historicamente, do Estado e dos agentes privados, desafia as inovaçōes democráticas das Constituiçōes. O não reconhecimento do "outro" colonizado pelo sujeito colonizador levou ao "assujeitamento" de negros, índios e camponeses cuja matriz é a exclusão territorial e o exclusivismo proprietário (Fonseca, 2015, p. 309).

Hegel (1770-1831), ao discorrer sobre os indígenas americanos, ilustra à perfeição a atitude discriminatória dos colonizadores face aos povos do Novo Mundo: "[...] ainda custará muito até que europeus lá cheguem para incutir-lhes uma dignidade própria. A inferioridade desses indivíduos, sob todos os aspectos, até mesmo o da estatura, é fácil de se reconhecer" (Hegel, 2008, p. 75). A apreciação negativa do colonizado encontra-se no âmago do projeto moderno, o qual não poderia ser levado a cabo sem o estabelecimento da ideia de que a colônia representa um polo atrasado, incivilizado e subdesenvolvido, quando comparada à metrópole, e que a primeira só teria a ganhar ao deixar-se organizar pela racionalização inerente a essa última (Dussel, 1993; Quijano, 2005). Nessa linha de raciocínio, se a racionalidade, em frequentes ocasiōes, descamba para a violência, isso não passaria de um mal necessário, uma etapa inevitável no "autodesenvolvimento do Espírito" (Hegel, 2011), que se objetivaria em instituições tais como o Estado, sua culminação máxima.

Já se tornou lugar-comum tomar o conflito como a expressão da animalidade humana, ao passo que a cooperação costuma ser associada ao exercício da razão, da qual todos os homens seriam dotados e que figuraria como seu principal atributo, consoante Descartes (2001). Nada mais distante da realidade, em que arranjos tidos como racionais, tais como a divisão parcelar do trabaIho e o direito, acabam por revelar-se brutais, por provocarem, em frequentes ocasiōes, o sofrimento físico e psíquico daqueles que se ocupam das funçōes mais penosas e pior remuneradas e o tratamento penal diferenciado, de caráter puniti- vista, a todos os que o sistema jurídico considera inimigos (Agamben, 2004). Contudo, o presente estudo não está restrito à análise dessa violência institucional, que já foi bem esquadrinhada em âmbito acadêmico, em teorias como a "colonização do mundo da vida pelo sistema" (Habermas, 1987) e a "sociedade disciplinar" (Foucault, 2014).

O interesse principal desse trabalho, na realidade, é a investigação de uma violência onipresente, que se faz notar em qualquer interação humana: a violência alteritária, voltada ao "alter", ao outro, que abarca a violência sistêmica - "forma esta alimentada por meio das coordenadas estruturais de reprodução das relaçōes sócio-econômicas, políticas e culturais" (Lustosa e Pires, 2017, p. 499) - sem, no entanto, reduzir-se a ela. Busca-se, assim, a compreensão da violência em um sentido amplo, no intuito de superar o colonialismo cotidiano, calcado na concepção do outro como objeto (Santos, 2011). Ou seja, a fim de dominar o outro, é preciso desumanizá-lo, e para tanto faz-se necessário, sob qualquer pretexto, tomá-lo como inferior. Nessa ótica, características distintivas de certos grupos sociais, como o gênero, a cor da pele, a nacionalidade, a orientação sexual ou a posse de recursos materiais servem como critério para hierarquização social, organizada em torno da dicotomia superior-inferior.

A violência alteritária intergrupal trata do choque entre diferentes culturas ou subculturas e é objeto de análise da Sociologia, ciência que não enfoca precisamente o indivíduo, mas sim o papel por ele desempenhado no interior de determinada instituição. Ela é melhor captada pela Sociologia do Conflito, que tem Marx (1818-1883) e Weber (1864-1920) como maiores representantes, embora as demais tradiçōes sociológicas - racional-utilitarista, microinteracionista e funcionalista também tenham algo a esclarecer em relação a mencionado fenômeno (Collins, 2009). Embora a hostilidade se manifeste com mais intensidade entre grupos sociais distintos, em que a cisão entre "nós", os integrantes de um mesmo grupo, e "eles", os membros do grupo alheio, é bastante 
pronunciada, ela também se faz notar dentro de uma mesma facção, na forma de uma violência alteritária intragrupal.

Basta lembrar que a família, grupo social por excelência, frequentemente é palco de violaçōes diversas, como a dos adultos contra crianças e adolescentes ou a cometida entre cônjuges. A ideia de nação, por sua vez, faz-se acompanhar do mito da unidade, que escamoteia diferenças a fim de "[...] homogeneizar, compactar para dominar" (Bagno, 2005, p. 56). Referidas assimetrias de poder no interior dos grupos são meIhor elucidadas pela Antropologia. Por último, é paradoxal que os homens, seres de conhecimento, desconheçam, ao fim e ao cabo, a si mesmos, a ponto de Rimbaud (2009) ter chegado à conclusão que "eu é um outro". O micro-interacionismo norte-americano, cujos expoentes são Charles Cooley (1864-1929) e George Herbert Mead (1863-1931), exibe uma compreensão semelhante, ao ressaltar a importância do contexto social na configuração da mente humana. A violência alteritária individual nasce dessa relação que o sujeito estabelece consigo mesmo, a qual resulta em conflitos internos passíveis de compreensão à luz da Filosofia e da Psicologia.

É desnecessário dizer o quanto da violência que grassa pelo mundo, direcionada tanto ao outro quanto ao eu, com a assunção, nesse último caso, de comportamentos autodestrutivos, deriva da ignorância que todos exibem, em última instância, quanto às próprias motivaçōes. A primeira solução que vem à mente, e que vai ao encontro das proposiçōes teóricas de Habermas (2013) e Apel (1991), é apostar na possibilidade do diálogo como meio de superar as divergências existentes entre os diferentes grupos que perfazem a totalidade social, expressão que designa, aqui, o conjunto dos grupos sociais que constituem, por intermédio das relaçōes que estabelecem entre si, a estrutura social. 0 problema reside justamente aí: como estimular a comunicação entre grupos sociais distintos, se ela "[...] só é possível entre iguais" (Wilson, 2013, p. 214)?
A comunicação entre diferentes, com efeito, não transcorre livremente e é repleta de ruídos, em decorrência do não reconhecimento pleno do interlocutor por parte daquele que, seja lá pelo motivo que for, se considera superior. Não obstante o projeto moderno tenha alcançado enorme sucesso no que se refere a seus aspectos instrumentais, com o crescente domínio da natureza, por intermédio da técnica, e a racionalização dos meios de trabalho, que elevou a produtividade a níveis nunca vistos, ele falhou fragorosamente no âmbito da ética, por não ter sido capaz de cumprir a promessa da expansão da liberdade humana. De fato, a afirmação da supremacia do indivíduo, um dos vértices da modernidade, não foi alcançada de forma plena no mundo contemporâneo, em que se assiste, de maneira contraditória, ao fortalecimento do poder dos grupos, em detrimento da autonomia individual.

Maffesoli chama essa primazia do grupo sobre o indivíduo de tribalismo, fenômeno que "[...] lembra, empiricamente, a importância do sentimento de pertencimento a um lugar, a um grupo, como fundamento essencial de toda vida social" (Maffesoli, 2006, p. 11). Até aí, novidade nenhuma, já que, desde Aristóteles (384 a.C. 322 a.C.), sabe-se que o homem é um animal social, dependente do outro para constituição de si mesmo. Desde que se nasce, já se está sob a tutela de outrem, seja para obtenção de cuidados básicos, seja para auferir aprendizado.

O que ocorre atualmente é que, com a perda de força do argumento religioso como fundamento último da ordem social (Eagleton, 2016), ao mesmo tempo que não se encontrou nenhum outro substrato de alcance universal para sustentar discursos, práticas e instituiçōes, os padrōes compartilhados de certo e de errado limitam-se cada vez mais a grupos específicos, o que redunda na ausência do estabelecimento de um consenso mínimo entre os cidadãos, indispensável à vida em conjunto. A guerra civil entre fortes e fracos, destarte, não se dá apenas em momentos críticos da história, renovando-se de modo sub-reptício e 
incessante, através de ataques como o deboche, a zombaria, o sarcasmo, o desprezo e o desdém, presentes de forma ubíqua nas relaçōes sociais.

O mal, por esse ângulo, não é episódico, como o discerne o senso comum, nem radical, como o considera Kant, mas banal e superficial, no sentido proposto por Hannah Arendt (1906-1975). O antídoto à banalidade do mal é o mergulho em profundidade no espírito humano, que se revela, por sua vez, ilimitado. Parte-se do pressuposto do conhecimento como um atributo fundamental de qualquer ser humano, por natureza propenso ao saber (Jaspers, 2011; Freire, 1996), e não como um privilégio de uma minoria, como advogam os beneficiários do establishment. A intuição arendtiana ecoa o ensinamento de Sócrates (469 a.C.-399 a.C.) de que mal e ignorância são coisas idênticas.

É oportuno consignar que a abordagem que se pretende aqui desenvolver não se baseia tão somente na descrição do acirramento dos ânimos observável na atualidade, causado, em grande medida, pela atuação enviesada de setores da imprensa e dos poderes judiciário, mas também na procura dos elementos invariáveis nesses episódios de rejeição da diferença. Faz-se mister, portanto, a adoção do método histórico-dialético, simultaneamente indutivo e dedutivo, capaz de, ao mesmo tempo em que parte de uma situação particular para o alcance de conclusōes de validade universal, também é apto a distinguir nuances dos fenômenos concretos, tendo como ponto de largada concepçōes mais amplas, de teor filosófico, antropológico, sociológico, jurídico, ou, numa palavra, interdisciplinar.

\section{2. Ética e conhecimento}

\subsection{Objetividade, subjetividade, história e linguagem}

O estudo de fatos atuais esbarra, de forma invariável, na objeção de que é impossível analisar com isenção o que se vive de imediato. Nessa refutação, a objetividade é tomada com um fim em si mesma e a emoção é vista como algo que, embora funcione como um componente indissociável de qualquer experiência, acaba por turvar, em frequentes ocasiōes, a percepção adequada do real, impedindo os seres humanos de visualizarem com clareza a realidade à sua volta. Assim, caberia a eles, quando muito, a compreensão $a$ posteriori das situaçōes que vivenciam, perspectiva que os coloca a reboque da marcha do tempo, como se estivessem eternamente atrasados em relação ao aqui e agora. Esse descompasso, constatável com mais facilidade na vertente tradicional da disciplina histórica, segundo a qual o relato do historiador só é fidedigno quando elaborado Ionge do calor do momento nele descrito, também se faz presente em determinadas instituiçōes responsáveis pela urdidura da trama social.

Entre tais atores coletivos, destacam-se a mídia e o poder judiciário, os quais merecem um olhar mais detido, no caso brasileiro, em razão do protagonismo por eles desempenhado na crise que o país atravessa. Idealmente, jornalistas e juízes devem exercer suas funçōes sem pender para nenhum dos lados que se confrontam na arena pública, expressão que alude ao território em que são travadas as tão comentadas lutas de classes, designadas por Karl Marx (1818-1883) como o motor da história. O princípio da impessoalidade, orientador de citada conduta, emana do ideal democrático, um dos pilares dos estados surgidos no bojo das revoluçōes do séc. XVIII. Na contramão desse preceito, os profissionais apontados, com indizivel cinismo, valem-se do argumento da objetividade para legitimar os desvios por eles cometidos no desempenho de suas tarefas, num grau de tendenciosidade até então sem paralelo.

Há poucos anos, o Brasil se destacava, em âmbito mundial, com feitos como a diminuição sensível da taxa de pobreza absoluta, a qual teve uma queda de 43,4\% em 1995 para 28,8\% em 2008 (Ipea, 2010). A política de conciliação de classes empreendida pelo ex-presidente Luís Inácio Lula 
da Silva, permitiu, por algum tempo, a estipulação de um esquema "ganha-ganha", que, conquanto não tenha levado a nenhuma mudança mais significativa na estrutura social, possibilitou a consecução de programas governamentais que ajudaram a mitigar um pouco o efeito pernicioso das desigualdades sociais. Numa inflexão drástica de tal política, os brasileiros assistem hoje, aturdidos, ao desmonte do estado social acenado pela Constituição Federal de 1988, detectável em retrocessos como a aprovação da PEC n 55/16, que congela as despesas do poder público federal, com cifras corrigidas pela inflação do ano anterior e artificialmente "em queda", por até 20 anos (Brasil, 2016).

Uma onda conservadora, em relação a qual os movimentos sociais não conseguiram, até agora, fazer frente, ameaça carregar de roldão direitos conquistados a duras penas, após décadas de luta. $\mathrm{O}$ ataque aos direitos sociais se faz acompanhar de enorme excitação nervosa, facilmente aferível em uma breve leitura nos espaços para comentários de sites jornalísticos e blogs noticiosos, nos quais são veiculadas, com cada vez mais frequência, especialmente na proximidade de períodos eleitorais, mensagens de teor impublicável. Não se pode, porém, render-se às circunstâncias, com a adoção de uma postura resignada, ancorada na ideia de que as coisas sempre foram assim, a menos que se pretenda viver de maneira infeliz, o que não é crível, por contrariar, a toda evidência, a tendência básica de todos os seres humanos, qual seja, o "desejo de bem-viver" (Ricoeur, 1991).

A resposta é adotar uma postura radical, não no sentido de encerrar-se em facciosismos, mas sim no de ".... agarrar a coisa pela raiz. Mas a raiz, para o homem, é o próprio homem" (Marx, 2013, p. 157). Resta saber o que é o homem, questionamento para cuja solução Marx oferece uma pista: "Mas o homem não é um ser abstrato, acocorado fora do mundo. O homem é o mundo do homem, o Estado, a sociedade" (Ibid., p. 151, grifo do autor). Dado que o utilitarismo, com sua equiparação entre bem e prazer, tornou-se, de maneira incon- teste, a doutrina ética mais difundida, em nível mundial, comprova a exacerbação do consumo, na maior parcela do planeta, vale a pena retornar à discussão, já levantada pelos gregos antigos, a respeito de qual é a essência humana.

É bem verdade que aqui se faz menção à interpretação popular do utilitarismo, em outras palavras, à maneira como tal doutrina foi assimilada pelo senso comum, apreciação marcada por um hedonismo quantitativo, estreitamente associado às primeiras elaboraçōes dessa teoria (Bentham, 1974) e que pode ser sintetizado na célebre fórmula: quanto maior a duração e intensidade dos prazeres ocasionados por uma ação, mais felicidade.

Stuart Mill (2001, p. 13), com a distinção entre prazeres superiores e inferiores, procurou corrigir as deficiências nas teses de seu padrinho Jeremy Bentham (1748-1832), como se pode depreender do seguinte trecho, bastante conhecido, da obra "Utilitarianism" (1863, p. 13, tradução nossa): "É melhor ser um ser humano insatisfeito que um porco satisfeito; melhor ser um Sócrates insatisfeito que um tolo satisfeito; e, se o tolo ou o porco tem uma opinião diferente, é porque eles só conhecem o seu próprio lado da questão". Ao salientar a proeminência dos prazeres superiores - os de cunho intelectual -, Mill retoma a prédica de que "[...] para o homem a vida conforme à razão é a melhor e a mais agradável, pois a razão, mais que qualquer outra coisa, é o homem" (Aristóteles, 2014, p. 222).

Como se vê, é plenamente possível, e, mais que isso, absolutamente necessário, o intercâmbio de ideias entre correntes teóricas que são, em sua aparência, conflitantes, tais como as éticas utilitarista e eudemonista. A predisposição ao diálogo se mostra salutar não apenas no âmbito teórico, mas também no prático, ambos, na verdade, indissociáveis entre si. À guisa de exemplo, aumenta a consciência de que a crise atual, tanto no nível local quanto no mundial, possui fundo ético, devido à assunção em larga escala 
de determinados valores utilitaristas, sem maior ponderação sobre o que constitui, efetivamente, a natureza humana.

Ganham relevo, em contraste com mencionado estado de coisas, as éticas do diálogo (Gadamer, 1997), da alteridade (Levinas, 2008; Buber, 1979), do reconhecimento (Honneth, 2003), do dom (Ricouer, 1991), do discurso (Apel, 2000; Habermas, 1989) e da responsabilidade (Jonas, 2006), as quais, sem embargo de eventuais incompatibilidades, compartilham a característica comum do apreço à diferença, ao outro, tidos por elas como aspectos inseparáveis do eu. A importância do outro na constituição do eu está fora de questão, tanto que o linguista Ferdinand de Saussure (1857-1913) já assinalava a diferença como algo essencial ao significado, o qual é, a seu turno, relacional, explica Stuart Hall (19322014): "Sabemos o significado de preto, Saussure argumentou, não pela existência de alguma essência da 'negritude', mas porque podemos contrastá-lo com seu oposto - o branco" (Hall, 2016, p. 153, grifo do autor).

O enfoque saussuriano carrega a inconveniência de um dicotomismo patente, incapaz de captar as gradaçōes de uma realidade formada mais pela combinação que pelo embate de extremos, exemplifica Hall: "[...] naquilo que chamamos de fotografia em preto e branco não há, na verdade, um puro 'preto' e 'branco', mas vários tons de cinza. O 'preto' tonaliza-se imperceptivelmente em 'branco', assim como os homens possuem um lado 'masculino' e outro 'feminino' em sua natureza" (Ibid., p. 154). Ademais, dificilmente há neutralidade nas oposiçōes binárias de uma cultura, demonstrou Jacques Derrida (1930-2004), que se insurgiu contra a opressividade da ideia de centro, pela qual um dos polos de determinado par antagônico é privilegiado, enquanto o outro é posto à margem.

A título de exemplo, os posicionamentos individualistas, classistas, machistas, racistas e colonialistas, dos quais, não raro, o capitalismo se reveste, expressam-se nas polaridades EU/outro, RICO/pobre, HOMEM/mulher, BRANCO/negro e METRÓPOLE/colônia, nas quais o elemento "central" foi grafado em caixa alta para destacar como o poder se imiscui no discurso. A inversão das polaridades - OUTRO/eu, POBRE/rico, MULHER/ homem, NEGRO/branco, COLÔNIA/metrópole -, possibilitada pelo "jogo das diferenças" (DERRIDA, 1995), prova que os sentidos tradicionalmente atribuídos às mensagens em geral não estão taIhados em pedra, e que, das lutas pelo poder encabeçadas por grupos historicamente marginalizados, pode advir a ressignificação de conteúdos, imprescindível à configuração de uma ordem social mais justa.

O problema fundamental é que, se é verdade que o significado não é nem fixo, nem absoluto, mas exsurge do diálogo (Bakhtin, 1981), também é verdadeiro que só há genuína comunicação entre os que se reputam iguais, aponta Robert Anton Wilson (1932-2007), de maneira que é muito difícil, para aquele que ocupa uma posição social dominante, reconhecer a humanidade dos que ele julga the serem inferiores. A criminalização do outro, a pretexto dele ser o portador da diferença, sempre foi uma estratégia de poder (Zaffaroni, 2015; Agamben, 2004; Benjamin, 2016), e não há quase nenhuma esperança de que as coisas sejam diferentes num horizonte próximo.

No Brasil, em geral, quando alguém diz "o brasileiro", não está se referindo a si mesmo. O "brasileiro", nessas ocasiōes, é sempre o outro, o que despreza as regras, o malandro, o responsável pelo fato do país não se tornar desenvolvido. Entretanto, deve-se resistir à tentação de atribuir o retrocesso atual a um pretenso vício atávico do povo brasileiro, que o tornaria inapto para a democracia. Como bem pontua Jessé de Souza (2015), o atraso nacional não se deve às razōes usualmente expendidas pelos intérpretes tradicionais da realidade nacional (Freyre, 2003; Holanda, 1995; Faoro, 2001), como o legado patriarcal da colonização portuguesa, arraigado nas instituições, ou a persistência de elementos da escra- 
vatura, que vigeu no território brasileiro durante mais de três séculos, mas sim a uma dominação onipresente, que se faz sentir, com maior ou menor intensidade, em todos as sociedades da Terra nas quais a divisão dos recursos disponíveis ocorra de maneira não equitativa.

A ressalva contida no parágrafo anterior não invalida, por óbvio, a contribuição dos intelectuais citados ao debate sobre os problemas brasileiros, cuja importância é indiscutível. Todavia, ela tem o mérito de chamar a atenção para o determinismo de certos discursos sobre o país, eivados, muitas vezes, de indisfarçável elitismo. Arthur de Gobineau (1816-1882), por exemplo, não teve nenhum receio em enxergar o déficit no desenvolvimento do Brasil como corolário da genética hipoteticamente desfavorecida de seus habitantes: "Nenhum brasileiro é de sangue puro; as combinaçōes dos casamentos entre brancos, indígenas e negros multiplicaram-se a tal ponto que os matizes da carnação são inúmeros, e tudo isso produziu, nas classes baixas e nas altas, uma degenerescência do mais triste aspecto" (in Raeders, 1988, p. 90).

Entretanto, embora a naturalização do social, pela qual o deslinde dos problemas históricos encontra-se na biologia, estivesse muito em voga na segunda metade do século XIX, atesta a extensa produção teórica da escola criminológica italiana, corporificada nos textos de Cesare Lombroso (1835-1909), Rafaelle Garofalo (1851-1934) e Enrico Ferri (1856-1929), ela se faz notar, desde sempre, no domínio intelectual. Já nos primórdios da filosofia ocidental, Platão (1965) concebe a sociedade como um organismo, formado por classes com funçōes estritamente delimitadas, quais sejam, de administração da pólis, defesa e produção de alimentos e materiais, a serem desempenhadas, respectivamente, pelos reis-filósofos, os soldados e trabalhadores em geral. Émile Durkheim (1999) segue na mesma senda, com sua distinção entre as solidariedades mecânica e orgânica, essa última responsável pela típica diferenciação do organismo social provocada pela divisão do trabalho.

As consequências do biologismo contemporâneo, porém, são muito mais graves que as das suas versōes precedentes. Ele se baseia, grosso modo, numa leitura enviesada, com fins ideológicos, das obras de Freud e Darwin ${ }^{1}$, e que resulta na prática, amplamente difundida, de um utilitarismo mal-ajambrado, baseado, sem maiores consideraçōes, em dois postulados: o móvel da ação humana é o prazer e a evolução resulta da vitória de indivíduos superiores sobre os inferiores, o que conduz ao aprimoramento da espécie humana. Daí para o extermínio em massa de populaçōes inteiras é só um passo, comprova a tentativa de aniquilação total do povo judeu na Segunda Guerra Mundial, por intermédio da "solução final".

Todavia, a conclamação de Adorno (1903-1969) para "[...] que Auschwitz não se repita" (Adorno, 1986, p. 33) soa um tanto ingênua se se pensar que, em certa medida, Auschwitz se repete a todo instante, em qualquer ato de negação do outro, cujo cerne é o desejo de destruição desse último, de imediato ou paulatinamente. No campo jurídico, a tentativa de temperar, com valores morais, a frieza das acepçōes positivistas, como resposta à barbárie nazista, não se revelou totalmente alentadora e tem dado azo aos subjetivismos mais inconsequentes, os quais, a médio ou longo prazo, podem resultar no descrédito do sistema judiciário como um todo.

O ativismo judiciário, por mais que possa estar imbuído de boas-intençōes, é encabeçado por atores que não se submetem ao crivo popular, o que the outorga um caráter antidemocrático (Streck, 2017). Isso posto, fica evidente que há uma relação próxima entre a forma como cada um se concebe,

${ }_{1}^{1}$ Para Owen Chadwick, ao contrário, a teoria de Darwin estava no caldo de renovaçāo político-cultural que no século XIX fazia o desmonte da tirania e do despotismo, pelo viés de secularização (CHADWICK, 2002, p. 28). 
imagem que recebe forte influência do grupo ao qual o sujeito está integrado (Woodward, 2015), e a maneira como ele se comunica com seus semeIhantes, o que torna premente aprofundar a reflexão sobre a essência humana.

\subsection{Essencialismo versus antiessencialismo}

Etimologicamente, essência deriva do latim "[...] essentia, a substância, a natureza das coisas" (Silva, 2014, p. 900), correspondendo, portanto, ao que faz de algo ou alguém aquilo que ele é. A filosofia ocidental, desde suas origens, busca um núcleo estável da cultura, em torno possam orbitar todas as açōes humanas, uma espécie de Santo Graal que assumiu configuraçōes variadas, no decorrer da história: physis, para os pré-socráticos; eidos, na filosofia platônica; a natureza, na filosofia helenística e Deus, na Idade Média. A peculiaridade do pensamento moderno é a transferência dessa causa primeira para a esfera subjetiva, de sorte que o "eu" passa a ser o substrato de quaisquer práticas sociais, o que ajuda a explicar o individualismo exacerbado que grassa pelo mundo afora na contemporaneidade.

Isso não quer dizer que a modernidade tenha abandonado a concepção objetivista, caracterizadora dos períodos filosóficos predecessores. A diferença é que, com o fortalecimento da classe burguesa, o supedâneo das condutas sociais é deslocado para a interioridade humana, o que não impede que a noção de objetividade seja uma das bases sobre as quais se assentam 0 edifício teórico moderno. A consequência mais notória dessa magnificação da objetividade é a instrumentalização da natureza, da qual os homens podem tornar-se "[...] senhores e possessores" (Descartes, 2001, p. 69), desde que utilizem o método adequado, apto a extrair daquela seus segredos (Bacon, 2003).

Semelhante afã colonizador do mundo natural acarreta, por conseguinte, a dominação do ser humano, não só porque esse último integra a na- tureza, como ser biológico que é, mas também, e sobretudo, porque a eleição da consciência como o polo inalterável de qualquer cognição, ínsita ao período moderno, acaba por engessar arbitrariamente uma realidade intrinsecamente fluida. Na segunda metade do século XIX, ao mesmo tempo em que o positivismo, decorrente das lições de Auguste Comte (1978), alcança grande difusão na Europa, com um discurso que relega a segundo plano a metafísica e a religião, nele consideradas fases inferiores do desenvolvimento intelectual humano, e coloca todas as fichas em conhecimentos passíveis de comprovação empírica, fortalecem-se produçōes teóricas que, apesar de não estarem totalmente livres das diretivas positivistas, lançam as bases para a contestação aos ideais modernos, em especial o da indivisibilidade do sujeito.

Como exemplos dessas conquistas intelectuais, tem-se a psicologia de Sigmund Freud (18561939), com sua apresentação do inconsciente como a verdadeira força propulsora do comportamento humano; o evolucionismo de Charles Darwin (1809-1882), para quem a espécie humana é só mais um ramo biológico, entre tantos outros; o materialismo histórico de Marx, que contempla a consciência como um construto social, erigido a partir dos materiais fornecidos pela classe social a que cada pessoa pertence, e a filosofia de Friedrich Nietzsche (1844-1900), que aponta os valores não como entes dotados de concretude, mas como avaliaçōes, variáveis, portanto, conforme o ângulo em que forem efetivadas. As duas guerras mundiais, na primeira metade do século XX, aprofundam a clivagem do indivíduo e deitam por terra o projeto iluminista do progresso ilimitado da humanidade, sob a égide da razão.

Ao universalismo da modernidade, consoante o qual todos os homens são dotados de dignidade, característica que os torna inestimáveis, contrapōe-se o particularismo sectário, em que só é dotado de humanidade plena aquele que faz parte do "grupo do 'eu"' (Rocha, 1984), expressão 
designatória de agrupamentos que vão desde a família até a nação. Tal facciosismo atinge o ápice no nazismo, com sua divisão da humanidade em superiores e inferiores - leia-se judeus, ciganos, homossexuais e pessoas com deficiência -, por meio da qual esses últimos são condenados a toda sorte de atrocidades em campos de concentração, de extermínio, de trabalhos forçados, dentre outros.

Na esteira desses acontecimentos, a filosofia contemporânea, nas suas diversas vertentes, tem enxergado o sujeito não como uma realidade apriorística, dada de antemão, mas como uma construção histórica, oriunda da linguagem. A atitude antiessencialista, inerente à filosofia contemporânea (Rorty, 1994), encerra características ambíguas, uma vez que, ao mesmo tempo em que possibilita a compreensão de que a realidade, no âmbito cultural, assemelha-se mais a uma construção permanente do que a uma obra pronta e acabada, finda por deixar as pessoas à deriva, sem um lastro estável onde possam ancorar suas realizaçōes e anseios.

A "pós-verdade", forma deturpada de relativismo, pela qual não há diferença substancial entre opinião e conhecimento, faz-se acompanhar do recrudescimento dos fundamentalismos mais arcaicos, nos domínios político e religioso, os quais vêm confundindo-se mais e mais, comprometendo a laicidade do Estado, um dos princípios basilares da democracia, regime que é, em seu âmago, plural.

\section{Violência, poder e colonialidade}

\subsection{Violência como luta por recursos}

Violência, de acordo com a etimologia da palavra, vem do "[...] étimo latino vis (que significa 'força'), também dá origem aos vocábulos 'vigor', 'vida' (de vis, vita) e 'vitalidade'" (Levisky, 2001, p. 217). Percebe-se, de imediato, que há uma relação intrínseca entre vida e violência, uma vez que, para sobreviver, é necessário valer-se, a cada instante, em maior ou menor grau, do emprego da força. Ao contrário de ser sempre manifesto, o uso da força muitas vezes ocorre de maneira velada, dissimulando-se sob a aparência de uma violência simbólica: "Qualquer campo social é necessariamente estruturado por um conjunto de regras não enunciadas para o que pode ser dito ou percebido validamente dentro dele, $e$ essas regras, portanto, operam como um modo do que Bourdieu denomina 'violência simbólica"' (Eagleton, 1997, p. 142).

Essa agressão insidiosa, porém, costuma ser mais incômoda do que a franca e aberta, por minar aos poucos o desejo de viver daqueles que dela são vítimas, em virtude do não reconhecimento, por parte de seus perpetradores, das demandas dos ofendidos (Honneth, 2003; Dunker, 2015). Não se pode deixar de mencionar que a violência silenciosa também é covarde, ao impedir que suas vítimas esbocem a pronta reação cabível nas situaçōes de conflito aberto. Para piorar a situação, os agredidos quase sempre são moldados a crer, pelo sistema cultural como um todo, que opera como legitimador da ordem normativa (Parsons, 1969), que o desprezo e a indiferença de que são alvo são naturais, que as coisas sempre foram assim e que não há muito o que se possa fazer a respeito. Por óbvio, os que propagam semelhantes ideias são os que lucram com elas, nas mais variadas instâncias, em especial no onipotente mercado, autêntico fiel da balança nos dias correntes, em relação ao qual todas as demais instituiçōes se encontram submetidas.

Para o ser humano atender a suas múltiplas necessidades, que o mantêm em permanente estado de alerta, não lhe basta pensar: ele deve, sobretudo, movimentar-se em direçōes diversas, ao encontro dos recursos capazes de aplacar essa tensão fundamental, os quais, além de, na maioria das vezes, não existirem de forma irrestrita, também são desejados por outras pessoas, o que dá ensejo a processos competitivos e cooperativos. A concepção do recurso como o elemento 
material indispensável à satisfação de uma necessidade humana baseia-se na premissa da concretude do mundo objetivo, o que afasta, de antemão, qualquer posição solipsista. É certo que o objetivo de saciar plenamente todos seus desejos é inalcançável para o homem, devido às várias limitaçōes que caracterizam sua condição, mas ele pode aproximar-se bastante dessa meta, caso seja dotado da porção adequada de poder, que corresponde, num sentido amplo, a "...] qualquer relação social regulada por uma troca desigual." (Santos, 2011, p. 266).

Conclui-se, portanto, que o poder, em vez de ser fixo e imutável, como sugerem determinadas concepções substancialistas, é fluido e relacional. Todo comportamento está voltado à obtenção de um determinado recurso, no objetivo de manter ou ampliar o bem-estar de quem assume a conduta em questão. Uma pessoa será tanto mais poderosa quanto mais recursos ela tiver à sua disposição. Na satisfação de suas carências, só resta ao homem envolver-se em conflitos com seus semelhantes ou negociar com eles. A violência está presente em ambos os processos e desponta, assim, como um elemento estrutural da sociedade, pois, ressalte-se, mesmo a cooperação não é isenta de violência, que subsiste em estado latente na maioria das interaçōes sociais. Um dos antídotos contra a violência que se esconde atrás da pretensa legitimidade do Estado de Direito Capitalista é desconfiar da universalidade da razão, faculdade que David Hume (1711-1776) considerou, acertadamente, "escrava das paixōes" (Hume, 2009, p. 451).

O conflito diz respeito, de modo invariável, à posse de um recurso qualquer, já antecipou Schmitt (2008), que via na dicotomia amigo/inimigo a essência da política, sendo amigo aquele que facilita o acesso a certo recurso e inimigo aquele que o dificulta. Poder, no sentido fenomenológico, é a capacidade da consciência humana moldar a realidade, e, uma vez que todas as pessoas nutrem o mesmo desejo de influir no real, conforme aquilo que Ihes seja conveniente, a atuação hu- mana não se dá sem oposição. O homem é um ser social porque o acesso aos recursos com os quais forja sua identidade lhe é franqueado pelos grupos aos quais está afiliado.

Correntes teóricas aparentemente antagônicas, como o materialismo histórico e a fenomenologia, guardam um ponto em comum: a noção de que não há ato desinteressado, posto que toda atitude tem um motivo, ainda que irracional, como se depreende, respectivamente, das ideias de ideologia e intencionalidade. A primeira diz respeito à facilidade com que as classes dominantes apresentam seus interesses particulares como se eles fossem um anseio geral, por deterem o controle dos "meios de produção espiritual" (Marx, 2010, p. 78), enquanto que a última emerge como um traço básico de qualquer vivência, sintetiza Franz Brentano (1838-1917): “Não há pensamento sem um objeto pensado, nem apetite sem um objeto apetecido" (in Santos, 2008, p. 89).

O interesse é o elo existente entre necessidade e recurso. A necessidade está para a interioridade humana assim como o recurso está para a exterioridade. No entanto, não há uma solução de continuidade entre mencionadas instâncias, que devem ser vistas de forma dialética. George Herbert Mead (1863-1931) argumenta que é a reflexividade que torna alguém humano, ao permitir que as pessoas tomem a si mesmas como objetos: "O self é algo reflexivo, que pode ser tanto sujeito quanto objeto, e que pode fazer-se objeto de si mesmo" (Collins, 2009, p. 217). Da mesma maneira que a posse de recursos comuns, por determinado grupo, ajuda a desenvolver o senso de pertencimento a essa coletividade específica, é a divisão diferencial dos recursos disponíveis que irá explicar a existência de inúmeros grupos sociais, mais ou menos poderosos.

\subsection{A violência alteritária $e$ colonialidade}

A dimensão da colonialidade nos estudos sociais e filosóficos é relativamente recente (Quijano, 
2005), mas propōe uma virada fundamental na percepção sistêmica do que é a modernidade, categoria de pensamento festejada e consolidada nas análises teóricas e críticas acerca da História e da realidade complexa, enfim. Pelo enfoque da colonialidade como elemento estruturante da modernidade, a violência alteritária adquire uma concreção histórica negativa: a violação direta de direitos e da condição do outro colonizado. A diferença racial e étnica se agudizou no experimento colonial, a hegemonia da metrópole se manifestou na violência "institucionalizada" e internalizada pelo outro colonizado (Fanon, 1968).

A violência colonial moderna e alteritária tem diferenças fundamentais projetando a hipótese histórica da violência como forma de relação entre os povos em que não há um viés racial explícita ou determinante antes da modernidade. A estatalidade, a assimetria técnico-científica e suporte do discurso ideológico são elementos da relação coIonial moderna que impactam qualitativamente a própria noção de "violência", conferindo a esta uma dimensão intrasubjetiva quase desconhecida nos conflitos "antigos". A modernidade como contexto da violência alteritária opera já no paradigma do sujeito-indivíduo e da compreensão filosófica "eurocentrada" do mesmo, por si mesma já uma violência ao outro colonial, a epistêmica. Ou seja, mesmo o discurso filosófico e científico acerca do ser humano tem uma matriz geo-epistêmica definida e metropolitana.

O choque entre povos ou coletividades em conflito não se dava sob as prerrogativas de poder do Estado, ente racional e burocrático moderno. A distinção clássica entre autoritas, potestas e status rei civitatis não alcança a estrutura racional e de poder que domina a modernidade, o Estado. O "outro" em face do qual a violência se torna estrutura de poder ela mesma é parte de uma coletividade subalternizada em face de indivíduos protagonistas do poder metropolitano. Esse aspecto da violência moderna impessoaliza no Estado a violência na mesma proporção (aproximadamente) da burocratização do Estado, a "banalidade do mal" conforme Hannah Arendt (1999). Santos (2011), ao definir o direito moderno como "estatal", reforça na seara específica do Direito essa nova centralidade a partir do centro de irradiação europeu-metropolitano.

A violência pessoal do potentado antigo e medieval contra o inimigo de corte conjuntural passa por um câmbio paradoxal: a vontade agressora passa a ser impessoal e burocrática, portanto aberta à dimensão coletiva dos atos de violência colonial, ao passo que os agredidos são uma coletividade, mas os efeitos profundos são na subjetividade individual dos colonizados. Na violência alteritária pré-moderna, o comando da autoridade pessoal e sua subjetividade são fundamentais, clássico exemplo da ira de Agamenon pelo rapto da esposa Helena que leva a guerra contra Tróia.

A assimetria técnico cientifica é outro aspecto da violência colonial. A superioridade nesse aspecto é construída a partir do padrão industrial do Ocidente, da produção em massa e daí a possibilidade de sujeição militar e econômica do "outro" colonial. Não é, portanto, a superioridade técnica no sentido mais amplo de produção de utilidades para a vida cotidiana, coisa que as populaçōes tradicionais possuíam de modo até mesmo mais adequado que os colonizadores, mas produção de coisas pelo homo faber (Arendt, 2007). A dissolução das sociedades baseadas nas técnicas artesanais foi parte da violência "industrial" e condição para a superação das economias familiares pela do dinheiro e dos indivíduos com alta mobilidade (Luhman, 2006, p. 127).

O terceiro aspecto da violência alteritária sob o prisma da "diferença colonial" é a legitimação argumentativa. O colonizador é o agente da civilização, vai contrapor à vida holística do colonizado a dualidade da civilização urbano-rural e do sagrado-profano, por exemplo no fenômeno da urbanização (Teixeira, 2009). A ideologia do avanço da civilização também se mostra na problemática do desenvolvimento, a violência colonial se apresenta na possibilidade de mudança 
progressiva ou regressiva das ordenaçōes sociais e suas instituiçōes (Ribeiro, 1998, p. 68).

A violência alteritária no contexto da colonialidade se manifesta fortemente no "mito da fronteira", da conquista da terra pela violência e portanto por ela se legitima as formas absolutas e exclusivas de propriedade tomada ao "outro" (Haila, 2016). A estigmatização do "outro" colonial pela doutrina da terra nullius como o não-ser abriu as portas para toda sorte de violência conta os povos autóctones. Humanistas europeus como Francisco de Vitória conceberam a "teoria da tutela" pondo a doutrina secular da tríade "comércio, cristianismo e civilização" acima das consideraçōes do humanismo teológico (GILBERT, 2016) e construíram a partir daí a doutrina da "guerra justa".

\section{Conclusão}

$\mathrm{Na}$ atualidade, os acontecimentos se sucedem com uma velocidade tão estonteante que parece impossível acompanhá-los. As notícias adquirem, em nível crescente, um tom espetaculoso, sobrepondo-se umas às outras, de maneira aterradora, num processo que acaba por sufocar qualquer tentativa de assimilação do conteúdo por elas reportado, o que diminui a capacidade de reação aos incontáveis desmandos ora cometidos. Os fatos são eloquentes e falam por si sós: a exploração ad nauseam do processo da Lava Jato pelas maiores empresas de comunicação do país, dirigidas pelas famílias Civita, Frias, Mesquita e Marinho, foi decisiva na desestabilização do governo de Dilma Roussef, que acabou impedida de exercer o cargo para o qual havia sido democraticamente eleita, em outubro de 2014.

É de conhecimento geral que a população brasileira vive hoje num ambiente altamente polarizado, em que o debate coletivo se pauta pela confrontação de posiçōes aparentemente antagônicas e excludentes. Como a situação brasileira assume contornos fictícios, vale a pena recorrer a uma analogia, na tentativa de elucidá-la: os estratos sociais brasileiros são como placas tectônicas, assentadas sobre um manto viscoso, que liberaram gigantesca quantidade de energia, provocando um abalo sísmico de proporçōes inauditas, ao entrarem em atrito, após deslocaremse de modo quase imperceptível. Tendo em conta o silêncio das panelas, até bem pouco tempo bastante estridentes, é permitido pensar que as manifestaçōes conservadoras, que redundaram na deposição de Dilma Roussef, tenham sido mais uma reação aos avanços sociais promovidos pelos governos petistas, em âmbito federal, do que a manifestação de indignação contra os episódios de corrupção que, é forçoso reconhecer, ocorreram nessas gestōes.

As discussōes são travadas em um clima em que imperam as paixões, o sentimento, o que, se por um lado confere autenticidade aos discursos proferidos, em razão da convicção que os inspira, por outro abre margem para episódios de violência física e psíquica, que têm se tornado cada vez mais recorrentes, em um processo com consequências nocivas ao bem-estar individual e ao convívio democrático. Democracia implica, sobretudo, contato com o outro. Resta saber, porém, quem ou o que é o outro. Frise-se, de antemão, que o outro não significa necessariamente aquele que é diferente do eu, porque este último é, para todos aqueles que dele têm consciência, tanto quanto para si mesmo, um outro.

No universo científico, no qual o ideal de neutralidade manifesta-se de forma bastante pronunciada, temas como bem-estar soam estranho, ainda mais na seara da ciência jurídica, que tem a objetividade como verdadeira pedra de toque. Como definir bem-estar, dirão os paladinos da imparcialidade, se esse é o tema subjetivo par excellence, isto é, se o aprazível para alguém pode ser detestável para outrem? No entanto, malgrado o positivismo tenha relegado a subjetividade a segundo plano, associando-a à imaginação, à fantasia, à abstração, ou seja, a tudo o que funcionaria como óbice à cognição plena da realidade circundante, ela irrompe como alternativa ao estabelecimento arbitrário de verdades imutáveis. 
Isso não significa negar a possibilidade da objetividade, questão que deve ser deixada em aberto, a ser respondida pelo empenho intelectual sistemático da arte, da ciência, da religião, enfim, de todas as expressōes do espírito humano. Depois da morte de Deus (Eagleton, 2016), o homem contemporâneo encontra-se à deriva, e mesmo sua própria desaparição tem sido aventada (Foucault, 1999). Fala-se até sobre o surgimento do pós-humano (Lecourt, 2005), ser híbrido gestado pela superestimação da técnica. Nessa conjuntura, a consciência humana desponta como última cidadela contra um empenho ininterrupto de colonização, consubstanciada no desejo de reger, em benefício próprio, o ritmo da vida alheia. O pensamento converte-se, desse modo, em ato de resistência.

\section{Referências bibliográficas}

ADORNO, Theodor. Educação após Auschwitz. In: COHN, Gabriel (Org.). Sociologia. Trad. Flávio R. Kothe, Algo Onesti e Amélia Cohn. São Paulo: Ática, 1986. p. 33-45.

AGAMBEN, Giorgio. Estado de exceção. Trad. Iraci D. Poleti. São Paulo: Boitempo, 2004.

APEL, Karl-Otto. Transformação da Filosofia 2: o a priori da comunidade de comunicação. São Paulo: Loyola, 2000.

Teoría de la verdad y ética del discurso. Barcelona: Ediciones Paidós Ibérica, 1991.

ARENDT, Hannah. Eichmann em Jerusalém: um relato sobre a banalidade do mal. São Paulo: Companhia das Letras, 1999.

A condição humana. Rio de Janeiro:

\section{Editora Forense, 2007.}

ARISTÓTELES. Ética a Nicômaco. Trad. Torrieri Guimarães. São Paulo: Martin Claret, 2014.

BACON, Francis. Novum Organum. Trad. Clemente Fernando Almori. Buenos Aires: Editorial Losada, 2003.

BAGNO, Marcos. Dramática da língua portuguesa: tradição gramatical, mídia e exclusão social. São Paulo: Ediçōes Loyola, 2005.

BAKHTIN, Mikhail. Marxismo e filosofia da linguagem. Trad. Michel Lahud e Yara Frateschi Vieira. São Paulo: Hucitec, 1981.

BENJAMIN, Walter. O anjo da história. Trad. João Barrento. Belo Horizonte: Autêntica Editora, 2016.
BENTHAN, Jeremy. Uma introdução aos princípios da moral e da legislação. Trad. Luiz João Baraúna. São Paulo: Abril Cultural, 1974.

BRASIL Constituição (1988). Emenda Constitucional no 95, de 15 de dezembro de 2016. Altera o Ato das Disposiçōes Constitucionais Transitórias, para instituir o Novo Regime Fiscal, e dá outras providências. Disponível em: http://legis.senado.leg.br/legislacao/DetalhaSigen. action?id=540698 Acesso em: 24. abr. 2017.

BUBER, Martin. Eu e tu. Trad. Newton Aquiles von Zuben. São Paulo: Cortez \& Moraes, 1979.

CHADWICK, Owen. The secularization of the european mind in the nineteenth century. Cambridge: Cambridge University Press, 2002.

COLLINS, Randall. Quatro tradiçōes sociológicas. Trad. Raquel Weiss. Petrópolis/RJ: Vozes, 2009.

COMTE, Auguste. Curso de filosofia positiva; Discurso sobre o espírito positivo; Discurso preliminar sobre o conjunto do positivismo; Catecismo positivista. Trad. José Arthur Giannotti e Miguel Lemos. - São Paulo : Abril Cultural, 1978.

DERRIDA, Jacques. A escritura e a diferença. Trad. Maria Beatriz Marques Nizza da Silva. São Paulo: Editora Perspectiva, 1995.

DESCARTES, René. Discurso do método. Trad. Maria Ermantina Galvão. São Paulo: Martins Fontes, 2001.

DUNKER, Christian Ingo Lenz. Mal-estar, sofrimento e sintoma: uma psicopatologia do Brasil entre muros. São Paulo: Boitempo, 2015.

DURKHEIM, Émile. Da divisão do trabalho social. Trad. Eduardo Brandão. São Paulo: Martins Fontes, 1999.

DUSSEL, Enrique. 1492: O encobrimento do outro: a origem do mito da modernidade: Conferências de Frankfurt. Trad. Jaime A. Clasen. Petrópolis/RJ: Vozes, 1993.

EAGLETON, Terry. A morte de Deus na cultura. Trad. Clóvis Marques. Rio de Janeiro: Record, 2016.

Ideologia: uma introdução. Trad.

Luís Carlos Borges e Silvana Vieira. São Paulo: Editora UNESP : Editora Boitempo, 1997.

FEREZ, Cecília Abdo. La cuestión de la Jurisdicción em la teoria política de la modernidade temprana. Revista Direito, Estado e Sociedade. n. 44 jan/jun 2014. p. 10-35.

FANON, Frantz. Os Condenados da Terra. Trad. José Laurênio de Melo. Rio de Janeiro: Civilização Brasileira, 1968.

FAORO, Raymundo. Os donos do poder: formação do patronato político brasileiro. São Paulo: Globo, 2001. 
FONSECA, Paulo Henriques da. Novo constitucionalismo latino-americano, a propriedade e colonialidade: entre rupturas e permanências de um modelo. In: RECHTD Revista de Estudos Constitucionais, Hermenêutica e Teoria do Direito. v.7, n.3, UNISINOS, São Leopoldo, RS, 2015. Disponível em: http://revistas.unisinos.br/index.php/RECHTD/ article/view/rechtd.2015.73.10 Acesso em: 04 ago. 2017.

FOUCAULT, Michel. As palavras e as coisas: uma arqueologia das ciências humanas. Trad. Salma Tannus Muchail. São Paulo: Martins Fontes, 1999.

Vigiar e punir: nascimento da prisão. Trad. Raquel Ramalhete. Petrópolis/RJ: Vozes, 2014.

FREIRE, Paulo. Pedagogia da Autonomia: saberes necessários à prática educativa. São Paulo: Paz e Terra, 1996.

FREYRE, Gilberto. Casa-grande \& senzala: formação da família brasileira sob o regime da economia Patriarcal. São Paulo : Global, 2003

GADAMER, Hans. Verdade e Método. Trad. Flávio Paulo Meurer. Petrópolis: Vozes, 1997.

GILBERT, Jeremie. Indigenous peoples' land rights under international law: from victims to actors. Leiden-Boston: Brill Nijhoff, 2016.

GRAMSCI, Antonio. Cadernos do cárcere. Trad. Carlos Nelson Coutinho. Rio de Janeiro: Civilização Brasileira, 2006. v. 2.

HABERMAS, Jürgen. Consciência moral e agir comunicativo. Rio de Janeiro: Ediçōes Tempo Brasileiro, 2013.

Teoría de la acción comunicativa, II: Crítica de la razón funcionalista. Madrid: Taurus, 1987.

HAILA, Anne. Urban land rente: Singapore as a property state. West Sussex: John Wiley \& Sons Ltda, 2016, 304 p.

HALL, Stuart. Cultura e representação. Trad. Daniel Miranda e William Oliveira. Rio de Janeiro: Editora PUC-Rio, Apicuri, 2016.

HEGEL, Georg Wilhelm Friedrich. Fenomenologia do espírito. Trad. Paulo Meneses. Petrópolis/RJ: Vozes : Bragança Paulista : Editora Universitária São Francisco, 2011.

Filosofia da Histó-

ria. Trad. Maria Rodrigues e Hans Harden. Brasília: Editora Universidade de Brasília, 2008.

HOLANDA, Sérgio Buarque de. Raízes do Brasil. São Paulo: Companhia das Letras, 1995.

HONNETH, Axel. Luta por reconhecimento: a gramática moral dos conflitos sociais. Trad. Luis Repa. São Paulo: Ed.34, 2003.

HUME, David. Tratado da natureza humana: uma tentativa de introduzir o método experimental de raciocínio nos as- suntos morais. Trad. Débora Danowski. São Paulo: Editora UNESP, 2009.

IPEA. Comunicados do IPEA no 58: Dimensão, evolução e projeção da pobreza por região e por estado no Brasil. Disponível em: http:/www.ipea.gov.br/portal/images/stories/PDFs/100713_comunicado58.pdf. Acesso em: 18 abr. 2017.

JASPERS, Karl. Introdução ao pensamento filosófico. Trad. Leonidas Hegenberg e Octanny Silveira da Mota. São PauIo: Editora Cultrix, 2011.

JONAS, Hans. O Princípio Responsabilidade: ensaio de uma ética para uma civilização tecnológica. Rio de Janeiro: PUC Rio, 2006.

LECOURT, Dominique. Humano pós-humano: a técnica e a vida. São Paulo: Loyola, 2005.

LEVINAS, Emmanuel. Totalidade e infinito: ensaio sobre a exterioridade. 3. ed. Lisboa: Ediçōes 70, 2008.

LEVISKY, Davis Léo (Org.). Adolescência e violência: açōes comunitárias na prevenção "conhecendo, articulando, integrando e multiplicando". São Paulo: Casa do Psicólogo/ Hebraica, 2001.

LUHMANN, Niklas. La sociedad de la sociedad. Trad. Javier Torres Nafarrate e Darío Rodríguez Mansilla. Ciudad de Mexico: Universidad Iberoamericana, Herder, 2006.

LUSTOSA, Maria Anita Vieira; PIRES, Márcia Gardênia Lustosa. Educação em tempos de "obscurantismo ideológico": violência, poder e ideologia como instrumentos de dominação no capitalismo global contemporâneo. In: (Vários) Poder, violência, ideologia e filosofia da educação. Fortaleza: Editora Nova Civilizaçāo, 2017.

MAFFESOLI, Michel. O tempo das tribos: o declínio do individualismo nas sociedades pós-modernas. Rio de Janeiro: Forense Universitária, 2006.

MARX, Karl. Crítica de filosofia do direito de Hegel. Trad. Rubens Enderle e Leonardo de Deus. São Paulo: Boitempo, 2013.

MARX, Karl; ENGELS, Friedrich. A ideologia alemã. São Paulo: Editora Martin Claret, 2010.

MENESES, Maria Paula. Corpos de violência, linguagem de resistência: as complexas teias de conhecimentos do Moçambique contemporâneo. In: SANTOS, Boaventura de Sousa; MENESES, Maria Paula (Orgs). Epistemologias do Sul. São Paulo: Cortez, 2013.

MILL, John Stuart. Utilitarianism. Ontário: Batoche Books, 2001.

PARSONS, Talcott. Sociedades: perspectivas evolutivas e comparativas. São Paulo: Livraria Pioneira Editora, 1969. 
PLATĀO. A república. Trad. J. Guinsburg. São Paulo: Difusão Européia do Livro, 1965.

QUIJANO, Aníbal. Colonialidade do poder, eurocentrismo e América Latina. In: LANDER, Edgardo (org). A coIonialidade do saber: eurocentrismo e ciências sociais. Perspectivas latinoamericanas. Buenos Aires: Colección Sur Sur, 2005, pp.118-142.

RAEDERS, Georges. O Inimigo Cordial do Brasil - O Conde de Gobineau no Brasil. Rio de Janeiro: Paz e Terra, 1988.

RIBEIRO, Darcy, O processo civilizatório: etapas da evolução sociocultural. São Paulo: Companhia das Letras, 1998.

RICOEUR, Paul. O si-mesmo como um outro. Trad. Luci Moreira Cesar. Campinas: Papirus, 1991.

RIMBAUD, Arthur. Correspondência. Trad. Ivo Barroso. Rio de Janeiro: Topbooks, 2009.

ROCHA, Everardo P. Guimarães. O que é etnocentrismo. São Paulo: Editora Brasiliense, 1984.

RODRIGUES, Nélson. A pátria de chuteiras. Rio de Janeiro: Nova Fronteira, 2013.

RORTY, Richard. A filosofia e o espelho da natureza. Trad. Antônio Trânsito. Rio de Janeiro: Relume-Dumará, 1994.

SANTOS, Boaventura de Sousa. Para um novo senso comum: a ciência, o direito e a política na transição paradig- mática. Conteúdo: V. 1. A crítica da razão indolente: contra o desperdício da experiência. São Paulo: Cortez, 2011.

SANTOS, Milton. A natureza do espaço: técnica e tempo, razão e emoção. São Paulo: Editora da Universidade de São Paulo, 2008

SCHMITT, Carl. O conceito do político/Teoria do Partisan. Trad. Geraldo de Carvalho. Belo Horizonte: Del Rey, 2008.

SILVA, Deonísio da. De onde vêm as palavras [recurso eletrônico]: origens e curiosidades da língua portuguesa. Rio de Janeiro: Lexikon, 2014.

SOUZA, Jessé. A tolice da inteligência brasileira: ou como o país se deixa manipular pela elite. São Paulo: LeYa, 2015.

STRECK, Lênio Luiz. O que é isto - o senso incomum? Porto Alegre: Livraria do Advogado Editora, 2017.

TEIXEIRA, Rubenilson Brazão. Da cidade de Deus à cidade dos homens. A secularização do uso, da forma e da função urbana. Natal: Editora da UFRN, 2009.

WILSON, Robert Anton. Ascensão de Prometeu. Trad. Camila Zanon. São Paulo: Madras, 2013.

WOODWARD, Kathryn. Identidade e diferença: uma introdução teórica e conceitual. In: SILVA, Tomaz Tadeu da. (Org.). Identidade e diferença: a perspectiva dos estudos culturais. Petrópolis/RJ: Vozes, 2014. p. 7-72.

ZAFFARONI, Eugenio Raúl. La cuéstion criminal. Buenos Aires: Planeta, 2015.

\section{Paulo Henrique Fonseca}

Doutor em Direito pela UFPE/Faculdade de Direito do Recife e mestre em Direitos Humanos pela UFPB. É professor adjunto da Universidade Federal de Campina Grande e Advogado. Coordena o PRODIH - Programa Institucional de Direitos Humanos e Acesso à Justiça da UFCG e é membro da Comissão de Direitos Humanos da UFCG.

\section{Leonardo Lani Abreu}

Possui graduação em Comunicação Social pela Universidade Federal de Mato Grosso do Sul (2003), graduação em Direito pela Universidade Federal da Grande Dourados (2008), mestrado em Geografia pela Universidade Federal de Mato Grosso do Sul (2006) e especialização em Direito Processual Civil pela Fundaçāo Escola do Ministério Público (2010). Atualmente é Auditor-Fiscal do Trabalho no Ministério do Trabalho e Emprego, Professor Adjunto no curso de Direito da Universidade Federal do Acre e doutorando no Programa de PósGraduação em Educação da Universidade Federal do Paraná. 